\title{
Awareness raising workshop for nursing students on the elderly with Alzheimer's disease: contributions to education
}

Oficina de sensibilização ao acadêmico de enfermagem sobre o idoso com doença de Alzheimer: contribuições ao ensino

Taller de sensibilización al académico de enfermería acerca del mayor con enfermedad de Alzheimer: contribuciones a la enseñanza

\begin{abstract}
Maurício Barros'
ORCID: 0000-0003-4333-4847

Claudia Zamberlan'

ORCID: 0000-0002-4664-0666

Maria Helena Gehlen'

ORCID: 0000-0003-3232-255X

Paloma Horbach da Rosa'

ORCID: 0000-0003-4463-1042

Silomar Ilha'

ORCID: 0000-0002-2132-9505
\end{abstract}

'Universidade Franciscana. Santa Maria, Rio Grande do Sul, Brazil.

How to cite this article:

Barros M, Zamberlan C, Gehlen MH, Rosa PH, Ilha S. Awareness raising workshop for nursing students on the elderly with Alzheimer's disease: contributions to education.

Rev Bras Enferm. 2020;73(Suppl 3):e20190021.

doi: http://dx.doi.org/10.1590/0034-7167-2019-0021

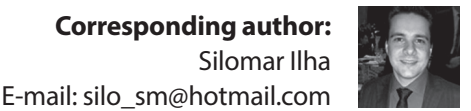

EDITOR IN CHIEF: Antonio José de Almeida Filho ASSOCIATE EDITOR: Andrea Bernardes

Submission: $02-10-2019$

Approval: 02-25-2020

\section{ABSTRACT}

Objective: To describe the contribution of an awareness-raising workshop for nursing students on Alzheimer's disease in the context of the elderly/family. Methods: Strategic action-research developed with 15 university students from the sixth to the eighth semester of Nursing at a university institution in the Rio Grande do Sul. The data collected through semi-structured interviews, before and after an awareness-raising workshop on Alzheimer's disease in elderly/family, were subjected to thematic content analysis. Results: Six categories were identified that concern (Mis) perception of Alzheimer's disease in the context of elderly/ family, from the characterization; risk factors; diagnosis; treatment of Alzheimer's disease; from care to family members/caregivers; and care strategies for the elderly with Alzheimer's disease. Conclusion: The awareness-raising workshop enabled the students to broaden and deepen the knowledge on the theme of Alzheimer's disease in the elderly.

Descriptors: Elderly; Alzheimer's disease; Family; Health education; Nursing.

\section{RESUMO}

Objetivo: Descrever a contribuição de uma oficina de sensibilização para o conhecimento dos acadêmicos de enfermagem sobre a doença de Alzheimer no contexto da pessoa idosa/família. Métodos: Pesquisa-ação estratégica desenvolvida com 15 acadêmicos do sexto ao oitavo semestre de Enfermagem de uma instituição universitária do Rio Grande do Sul. Os dados coletados mediante entrevista semiestruturada, antes e após uma oficina de sensibilização sobre a doença de Alzheimer na pessoa idosa/família, foram submetidos a análise temática de conteúdo. Resultados: Identificaram-se seis categorias que versam sobre o (Des)Conhecimento da doença de Alzheimer no contexto da pessoa idosa/família, a partir da caracterização; dos fatores de risco; do diagnóstico; do tratamento da doença de Alzheimer; do cuidado ao familiar/ cuidador; e das estratégias de cuidado à pessoa idosa com doença de Alzheimer. Conclusão: A oficina de sensibilização possibilitou ampliação e aprofundamento do conhecimento sobre a temática da doença de Alzheimer na pessoa idosa.

Descritores: Idoso; Doença de Alzheimer; Família; Educação em Saúde; Enfermagem.

\section{RESUMEN}

Objetivo: Describir la contribución de un taller de sensibilización para el conocimiento de los académicos de enfermería sobre la enfermedad de Alzheimer en el contexto de la persona mayor/familia. Métodos: Investigación - acción estratégica desarrollada con 15 académicos del sexto al octavo semestre de Enfermaría de una institución universitaria del Rio Grande do Sul. Los datos recogidos mediante entrevista semiestructurada, antes y después de un taller de sensibilización sobre la enfermedad de Alzheimer en la persona mayor/familia, han sido sometidos el análisis temático de contenido. Resultados: Se identificaron seis categorías que versan sobre el (Des)Conocimiento de la enfermedad de Alzheimer en el contexto de la persona mayor/familia, a partir de la caracterización; de los factores de riesgo; del diagnóstico; del tratamiento de la enfermedad de Alzheimer; del cuidado al familiar/cuidador; y de las estrategias de cuidado a la persona mayor con enfermedad de Alzheimer. Conclusión: El taller de sensibilización posibilitó ampliación y profundización del conocimiento sobre la temática de la enfermedad de Alzheimer en la persona mayor.

Descriptores: Mayor; Enfermedad de Alzheimer; Familia; Educación en Salud; Enfermaría. 


\section{INTRODUCTION}

The population aging process is a reality, both globally and nationally, and represents political, economic, social, and cultural challenges in the face of the demands of this population group, which refers to the need for planning and prioritizing public social policies ${ }^{(1)}$. With the aging process, the human being becomes susceptible to the appearance of specifics diseases of the age group, among which stand out chronic non-communicable diseases (NCDs) ${ }^{(2)}$.

Of the NCDs, we highlight those of a neurodegenerative character that concern dementia, especially Alzheimer's disease (AD), responsible for approximately $70 \%$ of cases in the elderly. It is considered progressive and irreversible, has an insidious onset, and leads to loss of functional capacity, spatial disorientation, and a gradual decline in memory, initially from recent events. These particularities, associated with other factors, characterize AD as difficult to diagnose $\mathrm{e}^{(3)}$.

The number of people with the disease exceeds 15 million worldwide; in the United States of America, there are 5.4 million people affected; of these, 5.2 million are older than 65 years old; and in the year 2050, every 33 seconds, a person will develop $A D^{(3)}$. In Brazil, about 1.2 million people have the disease, although most of them still do not have the diagnosis ${ }^{(4-5)}$.

The symptoms of $A D$ can be described in three stages or phases: initial, intermediate, and terminal. The initial phase lasts two to four years, on average, with recent memory loss and progressive difficulty in activities of daily living (ADLs). The intermediate phase ranges from two to ten years, with increasing memory loss, motor, language and reasoning difficulties, and ADLs. In the terminal phase, there is marked muscle stiffness, which significantly compromises the elderly, leading to a situation of fragility, vegetative state, and adoption of fetal position ${ }^{(6)}$.

Thus, AD causes significant changes in the life of the elderly, as well as that of family members/caregivers, who, in the Brazilian reality, are primarily responsible for daily care. This fact alerts to the need for nursing/health professionals to be prepared to act in this context. Thus, educational institutions in the health field must always be improving with a view to better teaching-learning for the care of the elderly/family.

The nurse is the professional responsible for the systematization of care for people; in this case, more specifically, the elderly in different contexts ${ }^{(2)}$. Thus, it is necessary to have clinical knowledge about the processes of life and aging, as well as about the primary diseases that affect people in each age group. The Política Nacional do Idoso (National Policy for the Elderly), already in 1994, referred to the need to include Gerontology and Geriatrics as curricular subjects in higher education courses in the health field $^{(7)}$. In 2006, the Política Nacional de Saúde da Pessoa Idosa (National Health Policy for the Elderly) was approved, which, in its guidelines, values permanent qualification in the area of elderly health, in order to encourage the development of research and teaching on the aging process ${ }^{(8)}$.

In this sense, research focusing on the (mis) perception of nursing students about $A D$ and care for the elderly/family becomes essential, to identify possible gaps, which can be minimized through interventions that contribute both to knowledge about the theme and, consequently, to care.
Among intervention methodologies, there are workshops characterized by participatory construction, in which there is an exchange of experience and knowledge between participants. The experiences arising from the workshops enable the production of participants' subjectivity and the construction of groups that are willing to meet each other and with moments of invention and reinvention of experienced situations $s^{(9)}$. However, as important as identifying the knowledge gaps and carrying out interventions, it is essential to assess the contribution of the intervention in the context studied.

Thus, the need and relevance of this study are justified in this assessment and in the necessity to reflect on the training of nurses concerning knowledge for caring of the elderly/family with chronic and neurodegenerative health conditions. This study can improve issues related to the teaching of care based on individualized attention to each human being, aiming at their autonomy and well-being ${ }^{(10)}$. Furthermore, issues related to the health of the elderly, family, and AD are of great importance in the health context, being highlighted as research priorities in Brazil ${ }^{(11)}$.

Based on these considerations, the question arises: What are the contributions of the awareness-raising workshop for nursing students on Alzheimer's disease in the context of the elderly/family?

\section{OBJECTIVE}

To describe the contribution of an awareness-raising workshop for nursing students on Alzheimer's disease in the context of the elderly/family.

\section{METHODS}

\section{Ethical aspects}

This study was submitted to the Human Research Ethics Committee for review, via Plataforma Brasil, CEP / CONEP system. Only after the CEP approval, the first contact with the participants was made. The ethical precepts that involve research with human beings were considered, according to Resolution 466/2012 of the Ministry of Health ${ }^{(12)}$. The Research Ethics Committee approved the project under opinion 2.516.885. The anonymity of the participants was maintained by identification by the letter $A$ (academic) followed by a number (A1, A2 ... A15).

\section{Type of study}

A strategic research-action type study, which proposes a transformation based on the researcher's prior knowledge of a given reality. Action research is a research model associated with several forms of collective action, oriented towards problemsolving, in which researchers and participants, representative of the situation or problem, get involved in a cooperative and participatory manner ${ }^{(13)}$.

\section{Study scenario}

Nursing students from a university in the state of Rio Grande do Sul, Brazil, participated in the study. They were selected by a draw in the attendance sheet, and we interviewed five students 
per class. The established inclusion criteria were: being a nursing student, attending the sixth to the eighth semester of the Nursing course at the studied institution, and having already taken the course of Gerontological Nursing and Clinical Medicine I, offered in the fourth and fifth semesters of the course, respectively. As exclusion criteria: not being in the classroom on the date of the draw for various reasons, such as medical certificate, academic exchange, among others. The nursing course at this institution has 63 years of training and is offered full-time for nine semesters. However, in the period of data collection, the course was in the process of changing the curriculum from eight to nine semesters. No students were attending the ninth semester.

The choice of the expected number of participants occurred because we understood that it was a sufficient number for projecting the knowledge of the students of the class. Based on this, 15 students met the inclusion criteria, forming the corpus of this study. After the draw and their acceptance, data collection was scheduled during March 2018 according to the availability of the participants.

\section{Data collection and organization}

Data collection was performed using a semi-structured interview instrument covering the following guiding questions: What do you know about Alzheimer's disease? What are the risk factors for Alzheimer's disease? How is Alzheimer's disease diagnosed? What is the treatment for Alzheimer's disease? How do you perceive the elderly and the family in the context of Alzheimer's disease?

The initial data (interview 1) were collected in a classroom at the university where the research was conducted. Wre invited each participant to answer, individually, the interview questions, while one of the researchers delivered the questions, waited, and clarified possible doubts related to them. Interviews were not recorded but handwritten by the participant after the researcher proceeded to each of the instrument's questions. After this initial stage of data collection, we scheduled with the participants for May 2018, the development of a workshop to raise their awareness of issues related to AD in the context of the elderly/family.

The workshop was conducted in a dialogue circle, in a classroom of the mentioned university and lasted for one hour. One of the researchers coordinated the activity, who is a nurse specialist in Gerontology, in the area of aging with AD. The coordinator started the workshop seeking to learn what the participants knew about the theme through their personal experiences or experiences learned during the training. Thus, participants were asked to register on an A4 piece of paper (distributed by the coordinator), through writing or illustration, as much information as they knew about the AD theme. Each participant was invited to present their construction to the others, which led to a productive discussion on the subject studied. After that moment, the coordinator explained the aspects related to $A D$, expanding some points and deepening others, as he perceived the need to or the participants requested.

On the same day, after the awareness-raising workshop, a new semi-structured interview (interview 2 ) was conducted with the same data collection instrument used previously and conducted by the same researcher who conducted the interview 1. Interview 2 aimed to assess the effectiveness of the awareness-raising workshop in the production of knowledge by nursing students about $A D$ in the context of the elderly/family.

\section{Data Analysis}

The data from the interviews were submitted to the content analysis technique ${ }^{(14)}$ from the three stages. Initially, the pre-analysis was carried out through skimming the materials, a moment that enabled a comprehensive understanding of the content. Then, an in-depth reading of the interviews was carried out, which made it possible to transcribe the results and significant passages. A new reading was performed, leading to the codification of the findings, in which the records allowed the elaboration of the categories. Through the three steps described, it was possible to view the content in an integrated way, relate the results and synthesize them, observing the convergences, divergences, and similarities.

\section{RESULTS}

Of the 15 students participating in the study, 100\% were female, aged between 20 and 27 years. Of these, five were in the sixth semester of the course; five, the seventh; and five, the eighth. From the data analysis, six categories emerged, which concern (Mis) Perception of Alzheimer's disease in the context of the elderly/ family, before and after the AD awareness raising workshop in the context of the elderly and family, as shown in Figure 1.

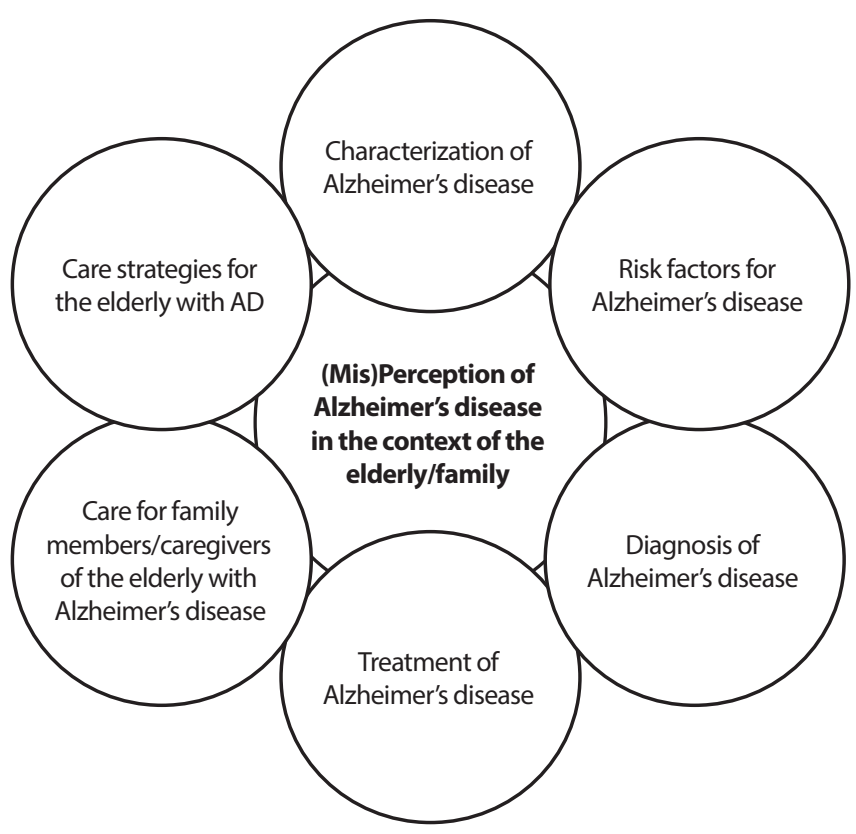

Note: AD: Alzheimer's disease

Figure 1 - Schematic representation of the relationship between the category and the subcategories

\section{Characterization of Alzheimer's disease}

Nursing students perceived $A D$ as degenerative morbidity that affects memory, which demonstrates the limited knowledge about this disease: 
It is a neurodegenerative disease that affects the elderly, causing a decrease in the brain. (A1)

A disease that affects the brain, causing the person to have memory loss. (A4)

It is a neurodegenerative disease, which leads to memory loss. (A5)

It is a disease that affects the brain, causes loss of memory, and cognition. (A7)

When conducting the interviews again after the awarenessraising workshop, we observed that this teaching-learning process served as a trigger for scientific knowledge concerning the theme, especially in the first questions asked. Regarding knowledge about the disease, the students demonstrated greater depth, which it is possible to observe in the statements:

$A D$ is a neurodegenerative, irreversible disease that mainly affects recent memory and has three stages, which are: mild, moderate, and severe. (A1)

It is a chronic degenerative disease that affects more the elderly because it is related to the aging process and is one of the causes of dementia, divided into three stages, ranging from some memory lapses to the total impairment of motor and cognitive ability. (A4)

It is a disease that has no cure and has three stages, mild, moderate, and severe, which gets worse as the disease progresses. Initially, recent facts are forgotten, and afterward, it increasingly compromises the cognitive and physical part. (A5)

It is a neurological disease, which affects the elderly more, compromising their quality of life, as it is divided into three stages, which gradually worsen the elderly's memory and judgment capacity and afterward even compromise their physical condition, leaving them restricted to the bed. (A7)

\section{Risk factors for Alzheimer's disease}

Before the awareness-raising workshop, nursing students recognized the genetic aspect as the leading risk factor for $A D$, as can be listed in the statements below:

Ah, the risk factors? They are genetic. (A2)

Genetic factors, as far as I know. (A3)

I think that genetic factors are the main risk factors. (A4)

Ah, the risk factors are genetic. (A5)

When we have redone the interviews, after the awareness-raising workshop, it was possible to notice that the answers were more consistent with the existing scientific evidence on the topic, which denotes the workshop's contribution to the knowledge of students:

The risk factors are many, and the age, genetics, and sedentary lifestyle are mainly punctuated. (A2)

Age, genetic factors, and lifestyle habits are risk factors for the disease. (A3)
Advanced age is the leading risk factor, in addition to lifestyle habits, such as poor diet, mental stress, and lack of physical activity. (A4)

As I said, it has the genetic factor, but mainly daily habits, such as physical activity, food, stress, etc. (A5)

\section{Diagnosis of Alzheimer's disease}

The reports also showed that being a complex disease, it raises doubts related to its diagnosis, since it has confounding factors and bias with other clinical conditions. Thus, the diagnosis was seen by students as follows:

The diagnosis? By brain tomography. (A2)

It is done by some memory tests. (A6)

Through computed tomography, which shows the areas of the brain affected by the disease. (A8)

It is done by several examinations, among them, physical examination and mainly by imaging, as the cerebral tomography. (A9)

After the workshop, it was possible to notice that students expanded their knowledge regarding the form of diagnosis since they referred to the clinical aspect, imaging exams and neurological tests that can be performed on the elderly:

The diagnosis is made by clinical and imaging tests, such as CT scans and MRIs, which are used to rule out other dementias. (A1)

Imaging exams, neurological tests performed on the person, and the clinical conditions of the elderly are listed as processes for diagnosis. (A2)

Clinical diagnosis is the most common, but imaging tests should also be performed to rule out other diseases. (A6)

The diagnosis is made based on the symptoms that will arise, from the history, anamnesis, imaging exam, such as magnetic resonance imaging, which serves mainly to rule out other pathologies that can be confused with Alzheimer's disease. (A8)

In addition to imaging, tomography, and magnetic resonance imaging, the clinic is also important, that is, observing and questioning the elderly and family members about daily behaviors [forgetfulness, confusion]. Tests such as Mini-Mental State Examination, for example, can also be used. (A9)

\section{Treatment of Alzheimer's disease}

As for the treatment for AD, the majority of the students participating in the study initially referred to it, basically, as medication therapy:

Medication is the treatment for the disease. (A1)

Drug treatment can alleviate symptoms [...] (A2)

Medicines to calm the elderly [...] (A3)

[...] I only know that they must take several medications. (A10) 
Medication therapy. (A12)

After the awareness-raising workshop, we observed that the students expanded their knowledge regarding the treatment before seen only as medication therapy. In addition to this form of treatment, they mentioned the no-medication, which includes activities that stimulate memory, healthy eating, physical activity, and multi-professional monitoring:

The treatment performed is medication and also memory exercising, physical activity, and healthy eating. (A1)

Encouraging people to do crossword puzzles, encouraging them to do a varied reading, manual activities, painting and learning new languages are part of the treatment of the elderly [...] (A2)

In addition to drug treatment, multidisciplinary monitoring is essential. (A3)

The medications help with the symptoms of the disease, but there is also a non-medication treatment that includes a series of manual and cognitive activities. (A10)

Mainly medication therapy, but also multiprofessional, as there are techniques that help the memory and can make the disease progress more slowly. (A12)

\section{Care for family members/caregivers of the elderly with Alzheimer's disease}

This category, as well as the latter, emerged after the awarenessraising workshop. The students showed concern with the care for family members/caregivers of the elderly with AD, as they began to realize that both have care needs because the disease causes changes in the lives of everyone who lives with the elderly:

For me, there are two victims of this disease because, if the family does not look for resources to help their relatives, they both end up lost and suffering. (A2)

I see how vulnerable they are, they seek a lot of information, and sometimes they don't know whom to turn to ... besides all the physical and emotional wear and tear of those who live with the disease and especially their family and caregivers. (A3)

The students were unanimous in emphasizing that the disease affects not only the elderly, but especially the family member/caregiver, who suffers from emotional and physical overload and, often, is not prepared to care for the person with AD in its different dimensions:

The caregiver/family member ends up suffering along with the person who has Alzheimer's disease and, therefore, care needs to be for everyone, even because there is an overload in those who spend more time with the patient. (A1)

There is a great difficulty between one caregiver and another, even because the person with $A D$ always has a person with whom there is a higher bond, and this is the person who is most burdened. (A4)

Sometimes, the family member who cares suffers more than the elderly with the disease, because they feel overwhelmed with so many care demands. (A13)

\section{Care strategies for the elderly with Alzheimer's disease}

The students mentioned the participation in support groups as a possible strategy to be used by family members in order to assist them in the process of living and caring for the elderly with AD:

Participating in support groups with dialogue circles, I think it is a relevant strategy. (A1)

Attending support groups for family members and people with Alzheimer's is a fundamental strategy to be used, as well as multiprofessional assistance. (A2)

Support with groups of caregivers is a great strategy. (A3)

[...] support group for caregivers is certainly a good strategy for caregivers to acquire knowledge and thus take better care of themselves and the elderly with Alzheimer's. (A15)

Other strategies mentioned by the students concerned the possibility of keeping older adults with badges and bracelets containing the contact of family members, as well as naming the environments and objects at home, to facilitate identification by the elderly with $A D$ :

I think it is important to keep the elderly identified with personal data and family members' contact through badges, bracelets. (A4)

It is important to place notes at home, identify materials and spaces with names to facilitate for the elderly with $A D$ to identify objects in the place where they live. (A6)

ID bracelet and badge is important because if the person gets lost, someone can view it and take the elderly home again. (A14)

\section{DISCUSSION}

$A D$ is still poorly understood by people in general, which can be explained, in part, by its neurodegenerative characteristic, without effective therapy for all cases ${ }^{(15)}$. This statement corroborates data from the present study, which showed that nursing students, initially, had limited knowledge about it. However, they expanded it after the awareness-raising workshop, when students began to understand it as neurodegenerative, irreversible, as a type of dementia that affects the elderly more.

Also, they began to understand the disease from the three stages. This understatement is in line with a study which describes the stages as: in the first stage of AD, considered mild, the elderly manifests confusion and memory loss, spatial disorientation, progressive difficulty in daily life, changes in personality and judgment; in the second, considered moderate, the disease evolves to the inability to perform the ADLs, in addition to anxiety, delusions, hallucinations, night agitation, sleep disorders, difficulties in recognizing friends and family; finally, the third and most serious stage is characterized by a marked reduction in vocabulary, decreased appetite and weight, unbalanced sphincter and fetal position ${ }^{(6)}$.

As the leading risk factor for $A D$, the students participating in this study recognized the genetic aspect. After the awarenessraising workshop, they began to recognize the predictors, of which 
they highlighted genetics, advanced age, physical inactivity, and life habits of each person. This data confirms that presented by the Alzheimer's Association, which describes that AD develops as a result of multiple factors, with age being the largest of them, since people aged 65 or over are more likely to develop it $^{(3)}$.

However, it should be noted that only the "age"factor does not necessarily imply developing $A D$, which justifies the active aging of many elderly. Other factors that influence it are genetics, family history, the risk for cardiovascular diseases associated with smoking, obesity, and diabetes ${ }^{(16-17)}$, fewer years of formal education, less social engagement, and traumatic brain injury $(\mathrm{TBI})^{(3)}$. Also, a study has associated chronic stress as a considerable risk factor ${ }^{(18)}$.

As for the diagnosis of the disease, the students initially referred that it occurred through imaging examination. After the awareness-raising workshop, they added the clinical aspect, symptoms presented by the elderly, imaging tests to rule out other dementias and neurological tests performed on the elderly. Therefore, it was possible to observe that, after the workshop, the students' knowledge expanded, deepened, and became more coherent with that presented in the literature.

A study developed by the Departamento Científico de Neurologia Cognitiva e do Envelhecimento da Academia Brasileira de Neurologia (Scientific Department of Cognitive Neurology and Aging of the Brazilian Academy of Neurology), that aimed at recommending new criteria for the diagnosis of dementia and AD in Brazil, found that the criteria for the diagnosis of $A D$ include cognitive and functional impairment. Such impairment reached at least two of the five domains: memory, language, executive function, visualspatial ability, and personality changes ${ }^{(19)}$. Besides, manifestations of insidious onset must be present, apparent cognitive worsening, cognitive deficits with a focus on language, memory, and space.

Magnetic resonance imaging (MRI) and computed tomography (CT) of the skull are recommended to exclude other diagnostic possibilities ${ }^{(19)}$. Despite efforts to arrive at the definitive diagnosis of $A D$, it can only be performed in current clinical practice through histopathological analysis of post mortem brain tissue. There is, therefore, no specific diagnostic test capable of confirming the presence of $A D$ in living humans.

The nursing students participating in this research recognized the use of medication as the only form of treatment for the elderly with AD. Such knowledge was expanded after the awareness-raising workshop when students also began to refer to non-drug treatment and to mention activities that stimulate memory, manual activities, healthy eating, physical activity, and multi-professional monitoring.

Pharmacological treatment is used to treat AD. It includes the use of cholinesterase inhibitor drugs, such as rivastigmine, galantamine, and cholinesterase. Such drugs cause changes in central cholinergic function, as they inhibit enzymes that degrade acetylcholine. For this reason, they increase the capacity of acetylcholine to stimulate brain muscarinic and nicotinic receptors, so that they improve the cholinergic neural pathway, compromised in $A D^{(20)}$.

In addition to pharmacological treatment, non-pharmacological treatment strategies should be used in an attempt to increase the quality of life of people with $A D$, since such strategies improve behavioral and psychological symptoms related to dementia. The non-pharmacological treatments most described in a systematic review were cognitive and multidisciplinary rehabilitation ${ }^{(21)}$.
Care for family members/caregivers of the elderly with AD was also mentioned by the students participating in the study after the awareness-raising workshop. According to the data, the elderly and the family member/caregiver have care needs, since AD causes changes in the lives of everyone who lives with the elderly in this condition.

The care of an older adult with AD produces emotional, psychological, and financial distress for the family member/caregiver, due to the demand for time of care that the elderly demand from the gradual loss of cognitive functions, which evolves into a situation of total dementia. For this reason, a reorganization of family members' lives is necessary so that the complications caused by the disease are overcome. Thus, care and daily living with the elderly with $A D$ lead to a significant change in the lives of family members/caregivers and, as a result, they are affected by stressful events, which reflects in the care provided to the elderly ${ }^{(22)}$.

In this regard, a study conducted with family caregivers of elderly with $A D$, in order to describe the repercussions of $A D$ on the family caregiver's life, mentions both the need to care for family members/caregivers and guidance on the disease and its evolution as well as the importance of developing educational and recreational activities aimed at integrating the family into social life. In the study, the authors describe as essential support for the health and quality of life of family members/caregivers and, consequently, for the care of the elderly with $A D^{(23)}$.

The students reported some strategies to assist family members in caring for and living with the elderly in the context of AD. Including participation in support groups, use of badges and bracelets with family members' contact, as well as naming rooms and objects in the home to facilitate their identification by the elderly with AD. Such data confirm other studies that present support groups as enhancers of care for family members/caregivers, as they assist in the production of knowledge and care for the elderly with $A D^{(24-25)}$.

The groups represent support, security, knowledge, and support, which provides greater comfort to face the adversities imposed by daily care ${ }^{(25)}$. The use of badges and bracelets with family members' contact was also a strategy evidenced in a study developed with professors of health courses at a higher education institution in the Rio Grande do Sul(2).

\section{Study Limitations}

This study had limitations inherent to any qualitative study, which, by its nature, does not intend to generalize its results. For example, we understand that there was only one awareness-raising workshop, which, although it had a positive impact, may not have reached its maximum potential. In addition, at the end of the research, the researchers realized that they could have expanded the range of questions - for example, about assessment instruments-, which could enable greater breadth and depth in some aspects inherent to care.

\section{Contributions to the nursing/ health field}

This study demonstrates the contribution to nursing as a profession since it helped in the teaching process during the training of professional nurses, a fact that possibly will have an impact on care for the elderly / families. Also, it is possible to understand its contribution to science, as it demonstrates the positive result 
after the use of an awareness-raising workshop, which can serve as a model for future research in different realities. Besides, we understand that from the data presented, new studies may appear, confirming, refuting, or just comparing the results. Thus, we suggest that more studies need to be developed in order to assist in the production of knowledge about aging and AD, as it is a disease that needs to be further explored.

\section{FINAL CONSIDERATIONS}

The results allowed describing the knowledge of nursing students about $A D$ in the context of the elderly/family, before and after an awareness-raising workshop. Before it, we identified a restricted knowledge about the issues related to $A D$ in the elderly/family, since the answers were, in their majority, generic or too broad. After the workshop, it was possible to identify the expansion and to deepen knowledge about the theme, as the students' answers were more detailed and consistent with what is found in the national and international literature on $A D$, which can lead to better care for the elderly / families. This fact denotes the contribution of the awareness-raising workshop to the knowledge of students on issues related to AD in the context of the elderly/family, and this can contribute to the care oriented to people in different settings.

\section{REFERENCES}

1. Miranda GMD, Mendes ACG, Silva ALA. O envelhecimento populacional brasileiro: desafios e consequências sociais atuais e futuras. Rev Bras Geriatr Gerontol[Internet]. 2016 [cited 2018 May 23];19(3):507-19. Available from: http://www.scielo.br/pdf/rbgg/v19n3/pt_1809-9823rbgg-19-03-00507.pdf

2. Ilha S, Backes DS, Backes MTS, Pelzer MT, Lunardi VL, Costenaro RGS. Family (re)organization of elderly with Alzheimer: the professors perception based on its complexity. Escola Anna Nery [Internet]. 2016 [cited 2018 May 23];19(2):331-7. Available from: http://www.scielo.br/ pdf/ean/v19n2/en_1414-8145-ean-19-02-0331.pdf

3. Alzheimer Association. Alzheimer's Disease Facts and Figures [Internet]. 2015 [cited 2016 Oct 05];11(3):332-84. Available from: https://www. alz.org/facts/downloads/facts_figures_2015.pdf

4. Associação Brasileira de Alzheimer (ABRAz). Doença de Alzheimer: "Alzheimer: quanto antes souber, mais tempo você terá para lembrar"[Internet]. 2012[cited 2018 May 23]. Available from: http://abraz.org.br/abraz-na-midia/release-institucional-doenca-de-alzheimer

5. Falco A, Cukierman DS, Davis RAH, Rey NAR. Doença de Alzheimer: hipóteses etiológicas e perspectivas de tratamento. Quim Nova [Internet]. 2016 [cited 2018 May 23];39(1):63-80. Available from: http://www.scielo.br/pdf/qn/v39n1/0100-4042- qn-39-01-0063.pdf

6. Sales ACS, Reginato BC, Pessalacia JDR, Kuznier TP. Conhecimento da equipe de enfermagem quanto aos cuidados com idoso Portador da doença de Alzheimer. Rev Enferm Cent O Min [Internet]. 2011 [cited 2018 May 23];1(4):492-502. Available from: http://www.seer.ufsj.edu.br/ index.php/recom/article/view/141

7. Presidência da República (BR). Leis, Decretos. Lei n. 8.842, de 04 de janeiro de 1994. Dispõe sobre a Política Nacional do Idoso, cria o Conselho Nacional do Idoso e dá outras providências [Internet]. Brasília (DF); 1994[cited 2018 May 23]. Available from: http://www.planalto. gov.br/cci-vil_03/leis/ I8842.htm

8. Ministério de Saúde (BR). Portaria n. 2528/GM, de 19 de outubro de 2006. Aprova a Política Nacional de Saúde da Pessoa Idosa [Internet]. Brasília (DF): Ministério da Saúde; 2006[cited 2018 May 23]. Available from: http://bvsms.saude.gov.br/bvs/saudelegis/gm/2006/\%20 prt2528_19_10_2006.html

9. Finocchiaro L, Imbrizi JM. Oficinas de arte e a formação em saúde: uma experiência no laboratório de sensibilidades da Universidade Federal de São Paulo (Unifesp) - Baixada Santista. Psicologia em Revista, Belo Horizonte [Internet]. 2017[cited 2018 May 23];23(1):274-91. Available from: http://pepsic.bvsalud.org/pdf/per/v23n1/v23n1a16.pdf

10. Sebold LF, Kempfer SS, Radünz V, Prado ML, Tourinho FSV, Girond JBR. Care is... nursing student perceptions: a Heideggerian perspective. Esc Anna Nery [Internet]. 2016 [cited 2018 May 23];20(2):243-7. Available from: http://www.scielo.br/pdf/ean/v20n2/en_1414-8145ean-20-02-0243.pdf

11. Ministério da Saúde (BR). Agenda nacional de prioridades de pesquisa em saúde. 2. ed., 2 reimpr. - Brasília: Editora do Ministério da Saúde, 2015. 68 p.

12. Conselho Nacional de Saúde. Diretrizes e normas regulamentadoras de pesquisa em seres humanos. Resolução $n^{\circ} 466$, de 12 de dezembro de 2012.

13. Franco MAS. Pedagogia da pesquisa-ação. Educ Pesqui [Internet]. 2005 [cited 2018 May 23];31(3):483-502. Available from: http://www. scielo.br/pdf/ep/v31n3/a11v31n3.pdf

14. Bardin L. Análise de conteúdo. Ed. São Paulo: Edições 70, 2011.

15. Ilha S, Backes DS, Santos SSC, Gautério-Abreu DP, Zamberlan C. Blasi TC. Group for family/caregivers of elderly with Alzheimer's: experience of teachers based on the complexity. Rev Rene [Internet]. 2015 [cited 2018 May 23];16(4):603-12. Available from: http://www.periodicos.ufc. $\mathrm{br} /$ rene/article/view/2735/2119

16. Deckers K, van Boxtel MP, Schiepers OJ, de Vugt M, Muñoz Sánchez JL, Anstey KJ, et al. Target risk factors for dementia prevention: a systematic review and Delphi Consensus study on the evidence from observational studies. Int J Geriatr Psychiatry. 2015;30(3):234-46. 
17. Borges MK , Jacinto AF, Citero VA. Validity and reliability of the Brazilian Portuguese version of the Australian National University Alzheimer's Disease Risk Index (ANU-ADRI). Dement Neuropsychol [Internet]. 2018[cited 2018 May 23];12(3):235-43. Available from: http:// www.scielo.br/pdf/dn/v12n3/1980-5764-dn-12-03-0235.pdf

18. Matos TM, Souza-Talarico JN. How stress mediators can cumulatively contribute to Alzheimer's disease An allostatic load approach. Dement Neuropsychol [Internet]. 2019 [cited 2018 Oct 10];13(1):11-21. Available from: http://www.scielo.br/pdf/dn/v13n1/1980-5764dn-13-01-0011.pdf

19. Frota NAF, Nitrini R, Damasceno BP, Forlenza O, Dias-Tosta E, Silva AB, et al. Critérios para o diagnóstico de doença de Alzheimer. Dement Neuropsychol. 2011;5(supl1):5-10. doi: 10.1590/S1980-57642011DN05030002

20. Wang J, Yu JT, Wang HF,Meng XF, Wang C, Tan CC, et al. Pharmacological treatment of neuropsychiatric symptoms in Alzheimer's disease: a systematic review and meta-analysis. J Neurol Neurosurg Psychiatry. 2015; 86(1):101-9. doi: 10.1136/jnnp-2014-308112

21. Carvalho PDP, Magalhães CMC, Pedroso JS. Tratamentos não farmacológicos que melhoram a qualidade de vida de idosos com doença de Alzheimer: uma revisão sistemática. J Bras Psiquiatr [Internet]. 2016 [cited 2018 Jul 15];65(4):334-9. Available from: http://www.scielo.br/pdf/ jbpsiq/v65n4/0047-2085-jbpsiq-65-4-0334.pdf

22. Carraro PFH, Magalhães CMC, Carvalho PD. Qualidade de vida de cuidadores de idosos com diagnóstico de Alzheimer e o emprego de acupuntura: revisão de literatura. Mudanças, Psicol Saúde [Internet]. 2016[cited 2018 Jul 15];24(2)65-70. Available from: https://pesquisa. bvsalud.org/ripsa/resource/pt/biblio-835055

23. Araújo CMM, Vieira DCM, Teles MAB, Lima ER, Oliveira KCF. The repercussions of Alzheimer's disease on the caregiver's life. Rev Enferm UFPE[Internet]. 2017 [cited 2018 Jul 15];11(2):534-41. Available from: https://periodicos.ufpe.br/revistas/revistaenfermagem/article/ view/11971/14517

24. Ilha S, Santos SSC, Backes DS, Barros EJL, Pelzer MT, Costenaro RGS. Complex educational and care (geron)technology for elderly individuals/families experiencing Alzheimer's disease. Rev Bras Enferm [Internet]. 2017 [cited 2018 Jul 15];70(4):726-32. Available from: http://www.scielo.br/pdf/reben/v70n4/0034-7167-reben-70-04-0726.pdf

25. Oliveira TI, Maziero BR, Ilha S, Pacheco LS, Oliveira FS. Daily family members/caregiver with Alzheimer: support group contributions. Rev Enferm UFPE[Internet]. 2017 [cited 2018 Jul 15];11(2):506-14. Available from: https://periodicos.ufpe.br/revistas/revistaenfermagem/article/ view/11968/14511 